\title{
PUBLIC SECURITY MANAGEMENT IN THE SOCIAL POLICY DOMAIN
}

\author{
Mariusz Paździor \\ Wyższa Szkoła Ekonomii i Innowacji w Lublinie \\ Wydział Administracji I Nauk Społecznych \\ ORCID ID: https://orcid.org/0000-0003-3873-3667 \\ e-mail: mpazdzior@pglaw.pl
}

\begin{abstract}
The purpose of the paper is to determine the subjective and objective scope of the public security management, identifying its goals and mechanisms which ensure public security in the social domain. It also aims at defining and evaluating the role of the state in the area covered by the article and constitutes an attempt of establishing an outlook pertaining to the range of the analysis undertaken. It is vital for the position of the state on the international arena and firstly and foremostly, because of maintaining social stability within the country. Implementing social policy goals in the planned and efficient manner translates into stability of the country, social welfare and creates possibilities for economic prosperity.
\end{abstract}

Keywords: public policy, public administration, public governance, participatory management, state security

\section{GENERAL REMARKS}

The state is the ultimate form of social groups and individuals organization and at the same time the effect of evolution of societies which have achieved a certain level of advancement. Along with the emergence of nation- states, the scope of the services provided by the state for the citizens was expanded. In practice, this meant the necessity to apply qualitatively new mechanisms and instruments, which would allow to perform numerous functions adopted by the state both assumed with regard to its citizens and as well as other international subjects. Such services are provided within the broadly understood management and relate to all spheres of the state functioning. One of the basic goals of the state is providing national security and managing the sphere of security and what follows, it requiers that the management of this area is efficient, effective, planned and targeted. This implies that the elements of randomness should be held to the 
minimum and as a principle, should have precedential nature in relations to the oncoming threats. The identified charcteristics of the security management can be applied to social policy as well. It is a special area of the state's interest because it pertains to the citizens security. This implies that the mechanisms directly adopted from management are not applicable here because as a principle social policy does not generate profit. Therefore, the catalogue of subjects and their role and involvement in the area of analysis will be significantly different from the role of subjects managing other subjects, especially in the private sector.

Beacuse of this significant and still growing role of security in the state functioning it is appropriate to address the question concerning the public security mangement and establish a model of the management. Since public security is the category implying a broad catatlogue of determinants and subjects whom it concerns, the article focuses on the social policy sphere. The choice of the area of analysis results from the author's conviction of a significant role of social policy in the state functioning, as well as from dynamics of changes in the area which extorts appropriate state's response. In the context of public security management in the social policy area, the state becomes a plane on which new quality bonds are created between the subjects of the policy. Concurrently, actions aimed at enhancing efficiency and effectiveness of the policy are enforced. Moreover, providing public security constitutes one of the state goals and functions. Its lack potentially generates threat and may, in extereme conditions, pose a threat to internal security. Therefore, the aim of the article is to indentify the subjective and objective scope of public security management, its goals and mechanisms applicable to its provision in the social policy area, as well as defining and assessing the role of the state in the subject discussed. It is important from the point of view of the state position on the international arena and firstly and foremostly, in maintaining social stability internally. Implementing the aims of the social policy in the pre-planned and efficient manner translates into the state stability, social well-being and creates opportunities for economic development. Discussing the subject seems to be appropriate because of the internal funtions ${ }^{1}$ the state assumes such as, among others: maintaining social order within the state organisation, providing broadly understood security in respect to the state's nationals, as well as providing social security, that is social assistance and health care to the citizens of the state. It is worth noticing that the contemporary role of the country comprises merging the state interest understood as the state apparatus with the interests and needs of individuals. Therefore, in the light of modern trends in public securtity perception, the role of an individual and citizen, as one of its basic subjects considered within human security is greatly appreciated.

1 Cf. M. Żmigrodzki, Wprowadzenie do nauki o państwie i polityce, UMCS, Lublin 2007, p. 14; A. Korybski, L. Leszczyński, A. Pieniążek, Wstęp do prawoznawstwa, UMCS, Lublin 2011; G. Seidler, H. Groszyk, A. Pieniążek, Wprowadzenie do nauki o państwie i prawie, UMCS, Lublin 2009; J. Krukowski, Wstep do nauki o państwie i prawie, Towarzystwo Naukowe KUL, Lublin 2004; J. Sobczak, Podstawy wiedzy o państwie i prawie, eSeM, Poznań 2002. 


\section{THE SCOPE OF PUBLIC SECURITY MANAGEMENT}

In the context of social policy and public security management, it is essential to identify the subjective and objective scope of public security mangement. Before identifying the scope, it is worth referring to the concept of public security management. Considering the fact that the state assumes responsibility for the provision of security considered in the largo category, it is essential to point out to the dominating role of the state in the subject scope discussed. It implies the necessity for merging the category of security and management with the descriptive term ,public" which in turn highlights the service character of the state in respect to its citizens, the state on which the responsibility of setting the main directions in the areas of its functioning rests, as well as the choice of measures and methods of the implementation of the identified golas. On the other hand, pointing to the management which pertains to the functioning of the state apparatus will denote its different nature in comparison to management in the private sector. Public management is traditionally prescribed to the state apparatus and originally it pertained to bureaucracy, which at the turn of the 19th and 20th century was equated with the positive revolution in public administration. Over the years, as a consequence of bureacracy expansion and due to its inefficiency, public administration has acquired pejorative characteristics. Public management was perceived as as prolonged process carried out by incompetent and often randomly chosen staff. Additionally, this negative perception of how bureaucracy, and also in the wider understanding, public administration functions was intensified by the economic and social changes at the begining of the 1990s, which in a sense, led to the growth of pathology in public administration (e.g. corruption). This was the context in which a search for an adequate method of management was commenced, the method which could addresss the negative phenomena in the scope discussed while taking into account the unchangeable character of public administration, which is ever aimed at providing variety of goods and public services e.g. providing access to education, healthcare, energy sources etc.

Simultaneously, the concept of public security is still not precise and has no clearly set limits'." It constitutes an element, next to general security and constitutional security, which is one of the pillars of on which internal security rests. Its goal is the protection of legal order of the country and defence against the

2 Cf. K.A. Wojtaszczyk, Istota i dylematy bezpieczeństwa wewnętrznego, „Przegląd Bezpieczeństwa Wewnętrznego" 2009, no. 1, op.cit., p. 14; E. Daniiloudi-Zielińska, hasło: Bezpieczeństwo wewnętrzne, [in:] Leksykon bezpieczeństwa. Wybrane pojęcia, eds. K. Dziubińska-Wójcik, R. Niedźwiecki, W. Saletra, A. Zagórska, Uniwersytet Jana Kochanowskiego w Kielcach, Kielce 2016, p. 74; B. Szmulik, Zagadnienia ogólne, [in:] Instytucje bezpieczeństwa narodowego, eds. B. Szmulik, M. Paździor, Wydawnictwo C.H. Beck, Warszawa 2012, p. 10; Bezpieczeństwo wewnętrzne RP $w$ ujęciu systemowy $i$ zadań administracji publicznej, eds. B. Wiśniewski, s. Zalewski, Wyższa Szkoła Administracji, Bielsko-Biała 2006, p.34-35 i 47; B. Sprengel, Ustrój organów administracji bezpieczeństwa i porządku publicznego WSH-E, Włocławek 2004, p. 13. 
prohibited behaviours, which are aimed at public order, life, health and property of the country's citizens ${ }^{3}$. One of the broadest definitions of public security was proposed by Bolesław Kuc i Zbigniew Ściborek who define it as ,,a whole array of conditions and institutions whose mission is to protect life, health and property of the cicizens of a country as well as the national substance, political system with its structure, and sovereignity of the country against phenomena destructive to legal order of the country and the phenomena that can interefere with the normal functioning of the citizens of the country and aimed at the generally accepted norms of conduct" ${ }^{4}$. Hence, public security can be defined as a category which reflects the codition of society as a whole and enables normal functioning of both the society and the state structures. Such an understanding of public security makes it one of the missions of the state institutions.

Therefore, the action of the state comprising the dynamics of socio-political changes which is aimed at addressing current and future widely interpreted social needs, can be understood as public security management. Thus, public security management becomes a targeted, planned and focused action aimed at the improvement of the social life quality, including the ever decreasing possibilities of the state in satisfying the social needs which constitute a seroious challenge for the state bodies 5 . At the same time the use of term ,public" denotes the major role of the state in the whole process, both in management and in security provision.

The above mentioned changes which add to the inefficiency of security management and force the actions which are aimed at developing and unifying procedures, models and norms which have not been applicable to the public administration structures so far as well as using quantitative indicators to measure the effectivness of the management processs. Public management has become a key form of implementing public tasks of the government administration which needs to be efficient and serve the purpose of realizing the interests of individuals and social groups in all walks of life 6 . Public management is a multilayered activity and comprises all the spheres of human life: education, health, energy, and most of all, security which is considered to be condition sine qua non for living, surviving and developing of individuals, societies and state structure. Managing public security is in line with the logic of fulfiling the role of service provision to the state's citizens.

3 M. Górski, hasło: Bezpieczeństwo publiczne, [in:] Leksykon bezpieczeństwa ...,p. 68; M. Paździor, J. Trubalska, Pojęcie bezpieczeństwa państwa, [in:] Bezpieczeństwo państwa w XXI wieku. Podręcznik akademicki,eds. M. Paździor, J. Trubalska, Ł. Wojciechowski, A. Żywicka, WSEI, Lublin 2018, p.14-26 [in print].

4 B. Kuc, Z. Ściborek, Podstawy metodologiczne nauk o bezpieczeństwie, PTM-Wydawnictwo Menedżerskie, Warszawa 2013, op.cit., p. 16.

5 E. Kotowska, Implementacja metod i narzędzi zarzadzania menadżerskiego $w$ sektorze publicznym, [in:] Zarzadzanie wartościami niematerialnymi w erze gospodarki rynkowej, ed. W. Harasim, Wyższa Szkoła Promocji, Mediów i Show Businessu, Warszawa 2015, p. 34.

6 J. Bourgom, Obywatel w centrum reform sektora publicznego, [in:] Zarzadzanie zmiana w administracji publicznej, ed. J. Czaputowicz, Krajowa Szkoła Administracji Publicznej, Warszawa 2012, p. 25. 
It is subjected to a continuos control by the citizens of the state. The characteristics of the public security management are: firstly, the time horizon in which the goals are identified, often limited by the term of office what constitutes the main fault in planning and implementing sector policies in the state. Secondly, due to the necessity of identifying the aims for the time range of five years maximum, also the expected results should be prompt thus making it difficult to define measurable results. Thirdly, because public security management aim is the implementation of a public interest, it will not produce the results in the form of profit but in the form of satisfying social needs, therefore the economic calculus does not determine the activites implemented in the public sector ${ }^{7}$. Fourthly, activities undertaken within the public security management are aimed at providing equality to citizens in the regulation of goods and services. Finally, management in the public sector is limited by the financial capacity as compared to the limitless social needs ${ }^{8}$. Therefore, the character of public security management has its own logic and specificity of functioning. At the same time the indispensable element of public security management is its multitasking character manifested by the need of undertaking multiple, varied tasks which are appropriate and proportional to the potential threats as well as preventive tasks which proactively identify risks, challenges and undertaking activities aimed at coordinating the system of the state's security'.

The subject scope of public security management pertains to providing conditions for economic and personal development as well as providing broadly understood security to the state's citizens manifested by, among others, improvement of the quality and standard of living of the citizens and increase in the social security. Thus, managing public security will be the category of the state activity focused, firstly and foremostly, on an individual. Activities which will be undertaken for the sake of security comprise initiatives aiming at decreasing unemployment rate, strengthening social integration, reducing social disparity, counteracting the problems relating to the consequences of demographic problems e.g. low birth rate or a problem of ageing population ${ }^{10}$. It should also be noted that the substantive scope of the state's public security management is connected stricto with the state's security system functioning in its universal dimension, therefore it comprises protection of the population, protection of goods and property, protec-

7 R. Fedan, Zarzadzanie publiczne w procesie kreowania rozwoju lokalnego i regionalnego, "Nierówności społeczne a wzrost gospodarczy” 2011 no 20, p. 211-212.

8 Cf. A. Kożuch, B. Kożuch, Ł. Sułkowski, E. Bogacz-Wojtanowska, M. Lewandowski, K. Sienkiewicz-Małyjurek, A. Szczudlińska-Kanoś, s. Jung-Konstanty, Obszary zarządzania publicznego, Monografie i Studia Instytutu Spraw Publicznych Uniwersytetu Jagiellońskiego, Kraków 2016, p. 8-9.

9 K. Sienkiewicz-Małyjurek, Organizacja i Zarzadzanie: kwartalnik naukowy, Zarzadzanie bezpieczeństwem publicznym w samorzadzie lokalnym - istota i inicjatywy, Wydawnictwo Politechniki Śląskiej, Gliwice 2011, p. 132.

10 K. Żukrowska, Pojęcie bezpieczeństwa i jego ewolucja, [in:] Bezpieczeństwo międzynarodowe. Teoria i praktyka, eds. K. Żukrowska, M. Grącik, Szkoła Główna Handlowa w Warszawie, Warszawa 2006, p. 44. 
tion of natural environment, protection against negative consequences of natural disasters and technical failures, ensuring fair living conditions ${ }^{11}$.

Personal scope of public security management, on the other hand comprises two main categories of subjects: the state and the citizens. The state understood as public administration and public organisations are in the first category while the citizens along with non-government organisations enter the second category ${ }^{12}$. The first group of subjects as indicated above comprises public institutions performing their public functions, that is public admninistration which can be defined as a set of organisational and executive activities, actions and undertakings implemented for the purpose of realizing a public interest by various subjects, organs and institutions based on the prescribed law and in the forms provided by the law"13. The described approach gives an impression that public administration and public management are identical concepts ${ }^{14}$. However, it is necessary to emphasize that there exists a qualitative difference between these concepts. In case of public administration empahasis is placed on subjects rendering a service to the public and as Dawid Sześciło notices private subjects are not included in the group even if they are authorised to provide a service for the public administration ${ }^{15}$. Therefore, it is the public administartion which is mainly burdened with the responsibility of catering to the collective needs, administration which acts within the limit of law and based on law. It is important to pay attention to the definitions of public administartion defining it as a system of institutions, which based on the adopted organisational assumptions function in the sphere of facts and social phenomena ${ }^{16}$.

The state is a compulsory, political organisation which integrates and settles social conflicts. It requires from the structure which is being analysed, to be equipped with the appropriate state apparatus which fulfills its functions. At this point, it is important to maintain balance between the compulsion and freedom and interference into the citizens' privacy. 1 The guarantee of this balance is functioning of the state based on the foundations of a democratic state of law, which refers to the duty of acting based on the provided law and within its limits. It has been emphasized in the provisions of art.2 of the Polish Republic Constitution ${ }^{17}$. It seems that the principles of a democratic state of law define in the direct and

11 W. Kitler, Obrona cywilna (niemilitarna) w obronie narodowej III RP, Akademia Obrony Narodowej, Warszawa 2009, p. 114.

${ }_{12}$ A. Kożuch et al, p. 8-9.

${ }^{13}$ H. Izdebski, M. Kulesza, Administracja publiczna. Zagadnienia ogólne, Liber, Warszawa 2004, op.cit., p. 93.

${ }_{14}$ D. Sześciło, Wprowadzenie, [in:] Administracja i zarzadzanie publiczne, eds. D. Sześciło, A. Mednis, M., Niziołek, J., Jakubek-Lalik, Stowarzyszenie Absolwentów Wydziału Prawa i Administracji Uniwersytetu Warszawskiego, Warszawa 2014, p. 17.

15 Ibidem,p. 17.

${ }^{16}$ M. Grzybowski, Administracja publiczna a tad konstytucyjny, [in:] Administracja publiczna, ed. J. Hausner, Wydawnictwo PWN, Warszawa 2008, p. 27.

17 Konstytucja Rzeczypospolitej Polskiej z dnia 2 kwietnia 1997 r. (Dziennik Ustaw 1997 no. 78 item 483 as amended). 
clear manner the scope of rights and freedoms of an individual and a citizen, as well as they point out the limits of interference and compulsion exercised on the part the state in respect to its citizens. Therefore, the state impelmenting its own interests and functions fulfills a number of premises which are aimed at ensuring the protection of the citizens' rights, through, amomg other means, the adequate intervention of the state in the social life and protection of the legally aquired rights. At the same time the state's intervention in the rights and freedoms of a person should be justified by the protection of the state's interests and/or protection of values accepted socially. At this point it is worth highlighting the fact that it is the state that guards the whole catalogue of protected values, which go beyond its functional frames and are inseparably connected with the protection of life, health and security of the state's citizens. It has been confirmed by the legal regulations. In the provisions of art. 5 of the Polish Constitution the legislator distinctly identified the protected values: independence and integrity of the territory, ensuring the freedoms and rights of persons and citizens as well as the security of its citizens, protection of national heritage and ensuring the protection of natural environment guided by the principle of sustainable development. Functionally, it is expressed in the right to a good administration, which constitutes a set of entitlements which are vested in citizens and concern their regulatory relations with the organs of the public administration and are ,aimed at protecting of a person's subjective rights ${ }^{18}$.

Additionally, the state performs a service function in respect to its citizens. Therefore, principally the subject which is the most efficient in achieving the designated goals and directions, and understood as the government apparatus, is the state. The state is a compulsory, political organisation integrating and settling social conflicts, it is sovereign, teritorial and is equipped with its characteristic apparatus performing specific functions. In practice, it stands for the necessity of developing an efficient management mechanisms. Hence, public administration defines and points the organs and institutions responsible for providing public services while public management refers to establishing functional relations between the two subjects. Public organisations, on the other hand implements activities for the public good aimed at realising the general public interests. This interest is valued by the society above the individual interest or the interest of the chosen social groups. Subjects such as: schools, public administration offices, hopsitals, fire services belong to the group of public bodies which provide services or products for the citizens. The public character of the service is present when these organs finance the service and assume responsibility for the service in front of the citizens. In practice, it means that other than social organisations can provide social services ${ }^{19}$. The effect of the processes of the state function evolution is determining the scope of the state's activity and division of competences between the public organs and

18 D. Sześciło, Prawo do dobrej administracji-narzędziem ochrony jednostki przed nadużyciem wtadztwa, [in:] Administracja i zarzadzanie..., op. cit., p. 76.

${ }^{19}$ E. Kotowska, Implementacja metod i narzędzi ..., s. 36. 
institutions and legal subject and individuals. It has a significant meaning to the citizens in the context of their human and citizen rights protection. Public administration and public organistaions act in complex and unpredictable environment which depends on many variables. From the point of view of the adopted goals, one of the fundamental variables is social unstability and political situation.

The second group of subjects comprises individuals and social organisations of the third sector, the so called non-government organisations, whose mission is acting in support of a specific groups of people.In their activities they are foremostly focused on performing social functions, implementing social equality, solving the specific local and regional problems etc. The social and economic changes contributed to addressing citizens as one of the major interesaries of the public security management. The participation of citizens in the public management is the expression of the civil society, which has led to establishing the group of external subjects of public management: non-government organisations, trade unions, lobby groups, political parties. As a result of the bottom- up tendencies and formation of informed society, the citizens started to demand that the public management performed its function efficiently. Within the framework of the civil society, citizens became involved in the decision making process and the process of defining the social interests. A broad catalogue of subjects can be included in the category: political parties, trade unions, social movements, non-profit organisations, autonomous universities and finally businesses. One of the key functions of the civil society is protection against the state's interference into a person's life. It is executed via the constant monitoring of the public authorities which is a new form of the control exercised over the authorities. Public governance in the public organisations focuses on preventing an excessive power concentration and minimalizing the negative effects of the power centralization. Also, the civil society aims at preserving the model of public management which concerns regulation of goods and services for the citizens based on equal access. It is worth mentioning that the necessary condition in the process of public management is international cooperation alongsidse with the realisation of activities which complement one another.

Public services are still the effect of values shared by the society. Simulataneously, the state creates conditions for compliance of the public organisations' aims and possibilities of their fulfillment, to the needs of the environment. Public management which includes public administration and the impulses sent by the broadly understood civil socjety, leads to creating public, private and social coalition what in principle makes the whole process of public services provision more efficient. The development of the civil society contributed to the empowerment of the citizen as the subjects which is not only the addressee of the state's support but firstly and foremostly, the causative subjects having influence on public management. Methods of social services provisions have innovative, cross-sectoral and interorganisational character ${ }^{20}$.

\footnotetext{
${ }^{20}$ A. Kożuch et.al, p. 16.
} 
Subjects of public management make up a complex group of institutions, government organisations and non-government organisations whose aim is ensuring and execution of public policy. It is not profit oriented and it is executed in the complex and unpredictable environment. The frames of achievement and and public policy realization are limited by legal regulations, which in in practice, make the procedures firmer and limits the possibilities of public management.

\section{THE ROLE OF THE STATE IN THE SOCIAL POLICY AREA.}

Considering the fact that the state understood as the state apparatus performs service functions in respect to its citizens, it is important to emphasize its function performed in the area of social policy. Social policy comprises both the function of providing service but also the function of safeguarding social welfare, health and lives of citizens. Social policy constitutes the practical activity of the state and in its most generic term it relates to creating conditions of living for people and shaping the relationship between the people. Social policy in Poland depending on the level of local government unit, performs many functions from establishing directions of social policy developmnet through job market policy, family policy and the disabled persons employability enhancement to combating poverty and public health policy.

Taking account the increasing needs of the society and limited resources of the state mentioned above, it is difficult to create system solutions which could establish efficient mechanism of catering to social needs. It, therefore, generates many challenges which the state bodies face. They are additionally aggrevated by the lack of instruments and a lack of definined measurable indicators, which are an indispensible elements of the diagnosis and activities programming, as well as financial shortages. As a result, developing the optimal model for the public security management in the social policy sphere is an extremely significant element, which translates into the efficiency of action in a given area.

The organs of the state undertake initiatives aimed at the improvement of of citizens' life, and these are correlated with the socio-economic situation of the country. Tendencies on the job market, demographic conditions, level of poverty etc. determine in a sense the scope of assistance for the groups requiring such support and help of the state.

In practice, it means there exists a necessity on the part of the state bodies at any level of undertaking proactive actions in relations to the tendencies manifested in economy and society. The realistic response to the challenges allows to programme solutions in the long-term perspective and what follows contribute to realizing the adoplted goals. Therefore, all the conditions important to the realization of the adopted goals are exteremly important in the context of public security management in the discussed area.

Defining the social policy determinants is the key element of public security management in the discussed sphere. It is worth mentioning that currently in 
Poland the trend of lowering birth rate is dominating and the fertility rate was 1,36 of the value of fertility rate, lower by 2,1 , which means that the process of population succession is below the simple generation replacement threshold ${ }^{21}$.

The identified situation is related to the increase of unemployment threat and lower employment stability as well as to a change of models among young people and their higher educational ambitions ${ }^{22}$. The decrease in the bitrh rate is correlated with the longer life span which gives rise to the phenomenon of ageing population. The changes in the age structure impact, on the other hand, the value of demographic dependency ratio which defines the relations between persons in an economically inactive age to the people of working age. In 2016 there were 29 people of non-working age for every 100 people of working age and 33 of post-working age. The forecast of the Central Statistical Office of Poland (GUS) points that in 2035 the ratio will have a value of 27 and 49 repsectively), in 2050 on the other hand will rise to 35 people in non-working age and 75 people in the post-working age ${ }^{23}$. Migration of people in the working age constitutes another challenge. This short characteristics of social policy determinants show how big the challenges the state faces are in the public security management in the social policy area.

While implementing social policy programmes, many changes in family policies concerning financial suport have been introduced since 2016, for example, among other changes, since January 1st, 2016 in the system of family benefits a principle of ,,a zloty for a zloty” has been introduced. The principle is based on gradual lowering of supplements to the family allowance and the reduction of the family allowance if the family income exceeds the income criterion which makes the family eligible for the allowance. Additionally, parental allowance of 1000 zlotys was granted to the persons who gave birth to a child but are not entitled to maternal benefit or maternal emolument. Also on April,1st childcare benefit (programme $500+)^{24}$ was introduced. Within social policy benefits the income criterion entitling to social benefit provision was raised in 2015 , so was the amount of the permanent and temporary benefits. Identifying the problem of aging population also contributed to implementation of the programme Senior + which is aimed at enhancing active participation of senior citizens in the social life $\mathrm{e}^{25}$.

The state, among its many functions, executes social policy. It preformes the key and superior role in respect to other institutions, organisations and citizens. As the only subject is equipped with competencies in goods regulations, defines the suport programmes, identifies the directions of social policy. Simultaneously,

${ }^{21}$ Sytuacja spoteczno-ekonomiczna gospodarstw domowych $w$ Polsce $w$ latach 2015-2016, Ministerstwo Rodziny, Pracy i Polityki Społecznej, Warszawa 2018, p. 7.

${ }^{22}$ I.E. Kotowska, Uwarunkowania zachowań prokreacyjnych, [in:] Diagnoza Społeczna 2013, Niska dzietność w Polsce w kontekście percepcji Polaków, ed. I.E. Kotowska, Ministerstwo Pracy i Polityki Społecznej i Centrum Rozwoju Zasobów Ludzkich, Warszawa 2014, p. 46.

${ }^{23}$ Sytuacja społeczno-ekonomiczna..., p. 9.

${ }^{24}$ Ibidem, p. 24.

${ }^{25}$ Ibidem, p. 26. 
it acts as a coordinator between the various institutions, therefore it is legitimate to ask about the preferred and more importantly, optimal model of public security management in the sphere of social policy.

\section{PUBLIC GOVERNANCE MODEL}

Public security management is a relatively sensitive process in which social welfare acquires primary meaning over income. Therefore, a simple impelmentation of solutions applied in management science will not produce the expected results in case these solutions are applied to public policy, security or political sciencies and may produce effect contrary to the expected ones. It is hence, essential to comprise the state determinants and its specificity as well as its function as a managing subject.

Public security management should be efficient and purposeful. When developing good practices and the standards of state's bodies functioning, it is worth to refer to the public governance model. Public management, as the author argues, failed in the social policy domain. Although, one of the model assumptions is flexible public administration but subsequent assumptions concerning setting goals aimed at achieving financial benefit in the long-term perspective will not remain valid.

In the context of public security management in social policy sphere it is wotrhwhile to refer to the public governance model, co-governance in other words. It fits into the social movements expressed within the civil society model and increased participation of citizens in the public life, decision making processes and administration itself gains social element in the decision making proces ${ }^{26}$. The model generates a number of actions aimed at controlling public administration and manifested by the continuous evaluation of the state apparatus functioning. It is justified in the context of an increased activity on the part of citizens, whose efforts are aimed at preventing excessive power concentration and execssive state interference into the freedoms and rights of a person and citizen. In the literature on the subject, it is pointed out that the management model discussed in this article serves to satisfy the higher needs ${ }^{27}$. The essence of the governance model is its networking character and blurring the borders and responsibility in response to its complexity and multidimensionality of social, political and economic problems. In connection with achieving and satisfying higher needs, it is appropriate to claim that public governece is more efficient when the basic needs have already been satisfied. Especially, the needs related to security. Therefore, the governance model in the public management is applicable in the area of social policy. Thus,

\footnotetext{
${ }^{26}$ E. Kotowska, Implementacja metod i narzędzi zarządzania..., p. 33.

${ }^{27}$ A. Kożuch et.al, s. 19.
} 
following the networking of relations between public and private subjects, the management will be efficient at the local level ${ }^{28}$.

Despite the growing role of non-public subjects in the decision making process, it does not seem that any imbalance or loss of the dominating role of the state is possible. The state still is and remains to be the guard fulfiling its role tin respect to its citizens. Its role has evolved however to the role of the coordinator, who sets the development directions, defines the volume and method of financial support, and sets the legal frameworks for cooperation. Bearing in mind the analysis conducted, it seems that the modern public management in the area of social policy should include social, economic, political utility and efficiency as well as transparency of information in the scope of the decisions made by the public administration.

Tytul: Zarządzanie bezpieczeństwem publicznym w obszarze polityki społecznej

Streszczenie: Celem opracowania jest wskazanie na zakres podmiotowy oraz przedmiotowy zarządzania bezpieczeństwem publicznym, wskazanie na jego cele oraz mechanizmy służące jego zapewnianiu w obszarze polityki społecznej, określeniu i ocenie roli państwa w podjętym temacie, a także próba stworzenia prognozy odnoszącej się w zakresie podjętej analizy. Jest to istotne z punktu widzenia pozycji państwa na arenie międzynarodowej, a przede wszystkim zachowanie stabilności społecznej wewnątrz państwa. Realizowanie celów polityki społecznej w sposób zaplanowany i skuteczny przekłada się na stabilność państwa, dobrobyt społecznych oraz stwarza możliwości rozwoju gospodarczego.

Slowa kluczowe: polityka publiczna, administracja publiczna, zarządzanie publiczne, zarządzanie partycypacyjne, bezpieczeństwo państwa

\section{REFERENCES}

1. Bourgom J. Obywatel w centrum reform sektora publicznego, [in:] Zarzadzanie zmiana w administracji publicznej, ed. J. Czaputowicz, Krajowa Szkoła Administracji Publicznej,Warszawa 2012.

2. Dziubińska-Wójcik K., Niedźwiecki R., Saletra W., Zagórska A. eds., Leksykon bezpieczeństwa. Wybrane pojęcia, red. K. Uniwersytet Jana Kochanowskiego w Kielcach, Kielce 2016.

3. Fedan R., Zarzadzanie publiczne w procesie kreowania rozwoju lokalnego i regionalnego, "Nierówności społeczne a wzrost gospodarczy" 2011 no 20, p. 202-218.

4. Grzybowski M., Administracja publiczna a ład konstytucyjny, [w:] Administracja publiczna, ed. J. Hausner, Wydawnictwo PWN, Warszawa 2008.

5. Hausner J. ed. Administracja publiczna, Wydawnictwo PWN, Warszawa 2008.

6. Izdebski H., Kulesza M., Administracja publiczna. Zagadnienia ogólne, Liber, Warszawa 2004.

7. Kitler W., Obrona cywilna (niemilitarna) w obronie narodowej III RP, Akademia Obrony Narodowej, Warszawa 2009.

${ }^{28}$ E. Kotowska, Implementacja metod i narzędzi..., s.33. 
8. Konstytucja Rzeczypospolitej Polskiej z dnia 2 kwietnia 1997 r., (Dziennik Ustaw 1997 no 78 item 483 as amended).

9. Kotowska E., Implementacja metod i narzędzi zarzadzania menadżerskiego w sektorze publicznym, [in:] Zarzadzanie wartościami niematerialnymi w erze gospodarki rynkowej, ed. W. Harasim, Wyższa Szkoła Promocji, Mediów i Show Businessu, Warszawa 2015.

10. Kotowska I.E., Uwarunkowania zachowań prokreacyjnych, [in:] Diagnoza Społeczna 2013, Niska dzietność w Polsce w kontekście percepcji Polaków, ed. I.E. Kotowska, Ministerstwo Pracy i Polityki Społecznej i Centrum Rozwoju Zasobów Ludzkich, Warszawa 2014.

11. Korybski A., Leszczyński L., Pieniążek A., Wstęp do prawoznawstwa, UMCS, Lublin 2011.

12. Kożuch A., Kożuch B., Sułkowski Ł., Bogacz-Wojtanowska E., Lewandowski M., Sienkiewicz -Małyjurek K., Szczudlińska-Kanoś A., Jung-Konstanty S., Obszary zarzadzania publicznego, Monografie i Studia Instytutu Spraw Publicznych Uniwersytetu Jagiellońskiego, Kraków 2016.

13. Krukowski J., Wstęp do nauki o państwie i prawie, Towarzystwo Naukowe KUL, Lublin 2004.

14. Kuc B., Ściborek Z., Podstawy metodologiczne nauk o bezpieczeństwie, PTM-Wydawnictwo Menedżerskie, Warszawa 2013.

15. Paździor M., Trubalska J., Pojęcie bezpieczeństwa państwa, [in:] Bezpieczeństwo państwa w XXI wieku. Podręcznik akademicki, eds. M. Paździor, J. Trubalska, Ł. Wojciechowski, A. Żywicka, WSEI, Lublin 2018, [in print].

16. Seidler G., Groszyk H., Pieniążek A., Wprowadzenie do nauki o państwie i prawie, UMCS, Lublin 2009.

17. Sienkiewicz-Małyjurek K., Organizacja i Zarzadzanie: kwartalnik naukowy, Zarządzanie bezpieczeństwem publicznym $w$ samorzadzie lokalnym - istota i inicjatywy, Wydawnictwo Politechniki Śląskiej, Gliwice 2011.

18. Sobczak J., Podstawy wiedzy o państwie i prawie, eSeM, Poznań 2002.

19. Sprengel B., Ustrój organów administracji bezpieczeństwa i porządku publicznego WSH-E, Włocławek 2004.

20. Sytuacja społeczno-ekonomiczna gospodarstw domowych w Polsce w latach 2015-2016, Ministerstwo Rodziny, Pracy i Polityki Społecznej, Warszawa 2018.

21. Sześciło D., Mednis A., Niziołek M., Jakubek-Lalik J. eds., Administracja i zarzązanie publiczne, Stowarzyszenie Absolwentów Wydziału Prawa i Administracji Uniwersytetu Warszawskiego, Warszawa 2014.

22. Szmulik B., Zagadnienia ogólne, [in:] Instytucje bezpieczeństwa narodowego, eds. B. Szmulik, M. Paździor, Wydawnictwo C.H. Beck, Warszawa 2012.

23. Wiśniewski B., Zalewski S. eds., Bezpieczeństwo wewnętrzne RP w ujęciu systemowy i zadań administracji publicznej, Wyższa Szkoła Administracji, Bielsko-Biała 2006.

24. Wojtaszczyk K.A., Istota i dylematy bezpieczeństwa wewnętrznego, „Przegląd Bezpieczeństwa Wewnętrznego" 2009, no. 1, p.14-15.

25. Żmigrodzki M., Wprowadzenie do nauki o państwie i polityce, UMCS, Lublin 2007.

26. Żukrowska K., Pojęcie bezpieczeństwa i jego ewolucja, [in:] Bezpieczeństwo międzynarodowe. Teoria i praktyka, eds. K. Żukrowska, M. Grącik, Szkoła Główna Handlowa w Warszawie, Warszawa 2006. 